\title{
PERKEMBANGAN FIQH PADA ERA MODERN SERTA PARA TOKOHNYA
}

\author{
Azman
}

Fakultas Syariah dan Hukum Universitas Islam Negeri (UIN) Alauddin Makassar

\begin{abstract}
This writing discusses the development of Fiqh in the Modern Era and the characters in which the development of this figh includes periodization Development of Sociology History of Islamic Law, Modernism toward the rationalization of Islamic teachings, The factors behind the emergence of the modernist group, Characteristics of the modernist group, the condition of Islamic law today, System studying the modern fiqh, the Islamic Tajdjid (Reformers), the Conditions of Muslims in Muslim Minority Countries in the Moderate Period, the application of the Fiqh Reality methodology in the case of Contempore Figh, and the cost of living in a Modern family. This movement is a flow in Islam that the mindset in accordance with modern development. Islamic Modernism is a movement to adapt Islamic teachings to modern thought and institutions. Modernists in Arabic are often associated with the term tajdid, which means renewal. Its character is called mujaddid, meaning reformer.
\end{abstract}

Keywords:

Contemporary Fiqh, Modern Era, Movement

\begin{abstract}
Abstrak
Penulisan ini membahas tentang Perkembangan Fiqh Pada Era Modern Serta Para Tokohnya dimana pada perkembangan figh ini meliputi Periodesasi Perkembangan Sejarah Sosologi Hukum Islam, Modernisme menuju rasionalisasi ajaran islam, Faktor-faktor yang melatarbelakangi munculnya kelompok modernis, Karakteristik kelompok modernis, Kondisi hukum Islam masa kini, System mempelajari fiqih modern, Tokoh-Tokoh Tajdjid (Pembaru) Islam, Kondisi Umat Islam Di Negara-Negara Minoritas Muslim Pada Periode Moder, Aplikasi metodologi Fiqih Realitas dalam kasus Fiqih Kontempore, dan Biaya hidup dalam keluarga Modern. Gerakan ini merupakan aliran dalam Islam yang pola pikir sesuai dengan perkembangan modern. Modernisme Islam adalah gerakan untuk mengadaptasi ajaran Islam kepada pemikiran dan kelembagaan modern. Modernis dalam bahasa Arab sering diasosiasikan dengan istilah tajdid, yang diartikan pembaharuan. Tokohnya disebut mujaddid, berarti pembaharu.
\end{abstract}

\section{Kata Kunci:}

Figh kontemporer, Era Modern, Gerakan 


\section{PENDAHULUAN}

\section{A. Latar Belakang}

$\mathrm{P}$ eriode modern dalam sejarah islam bermula dari tahun $1800 \mathrm{M}$ dan berlangsung sampai sekarang. Diawal periode ini kondisi dunia islam secara politis berada dibawah penetrasi kolonialisme. Baru pada pertengahan abad ke-20 M, dunia Islam bangkit memerdekaan negerinya dari penjajah barat. Periode ini memang merupakan zaman kebangkitan kembali islam, setelah mengalami kemunduran diperiode pertengahan. Pada periode ini mulai bermunculan pemikiran pembaharuan dalam islam. Gerakan pembaharuan itu paling tidak muncul karena dua hal. Pertama, timbulnya kesadaran dikalangan ulama bahwa ajaran-ajaran "asing" yang masuk dan diterima sebagai ajaran islam. Ajaran-ajaran itu bertentangan dengan semangat ajaran islam yang sebenarnya, seperti bid'ah, khurafat, dan takhyul. Ajaran-ajaran inilah, menurut mereka, yang membawa islam menjadi mundur. Oleh karena itu, mereka bangkit untuk membersihkan islam dari ajaran atau paham seperti itu. Gerakan ini dikenal sebagai gerakan reformasi. Kedua, pada periode ini barat mendominasi dunia dibidang politik dan peradaban. Persentuahn dengan barat menyadarkan tokoh-tokoh islam akan ketinggalan mereka. Karena itu, mereka berusaha bangkit dengan mencontoh barat dalam masalah-masalah politik dan peradaban untuk menciptakan balance power.

\section{B. Rumusan Masalah}

Dari latar belakang diatas, kami dapat mengambil rumusan masalah yang akan kami ulas, diantaranya yaitu:

1. Bagaimana Periodesasi Perkembangan Sejarah Sosologi Hukum Islam ?

2. Faktor-faktor apa saja yang melatarbelakangi munculnya kelompok modernis ?

3. Siapa SajakahTokoh-Tokoh Tajdjid (Pembaru) Islam Masa Sebelum Abad ke-19?

4. Bagaimana Kondisi Umat Islam Di Negara-Negara Minoritas Muslim Pada Periode Modern?

5. Bagaimana Kondisi Umat Islam Di Negara-Negara Mayoritas Muslim Pada Periode Modern?

\section{Tujuan dan kegunaan Penulisan}

Adapun tujuan dari penulisan ini adalah untuk menemukan secara umum konsep perkembangan fiqh pada era modern serta para tokohnya. Penulisan ini akan menelusuri konsep tersebut secara tematik.

Sedangkan kegunaan penelitian untuk menambah pengetahuan tentang perkembangan fiqh pada era modern serta para tokohnya yang dimaksud dan dapat menjadi bahan renungan dalam menumbuhkan semangat pekembangan fiqhi. 


\section{PEMBAHASAN}

\section{A. Periodesasi Perkembangan Sejarah Sosologi Hukum Islam}

Para penulis sejarah hukum islam telah mengadakan pembagian tahap-tahap pertumbuhan dan perkembangan hukum islam. Pembagian kedalam beberapa tahap itu tergantung pada tujuan dan ukuran yang mereka pergunakan dalam mengadakan pertahapan itu. Ada yang membaginya kedalam beberapa tahapan. ${ }^{1}$

Di Dunia Timur di rintis oleh pakar seperti Muhammad Khudaeri Bek yang dalam bukunya Tarik Tasyiri al-islami (Sejarah perkembangan hukum islam) menjelaskan pertumbuhan dan perkembangan hukum islam dengan mengaitkan sejarah sosial yang mempengaruhinya.

Dalam bukunya tersebut, Hudaeri bek membagi sejarah pertumbuhan dan perkembangan hukum islam menjadi 6 periode yaitu:

1) Periode Rasulullah (610-632)

2) Periode para sahabat besar sejak dilantiknya Abu Bakr as-Shidiq sebagai khalifah sampai dengan akhir masa pemerintahan Khalifah Ali bin Abi Thalib

3) Periode sahabat kecil yang berlangsung hingga akhir abad ke-1 $\mathrm{H}$

4) Peride fiqih muncul sebagai disiplin ilmu yang ditandaidengan lahirnya sejumlah ahli fiqih terkenal dan mempunyai pengikut yang mengembangkan pemikiran mereka menjadi mazhab

5) Periode terjadinya sebagai masalah hukum dan mazhab islam serta ditandai pula denganmunculnya pengarang-pengarang fikih terkenal.

6) Periode taklid dan pembaharuan hukum islam yang hingga sekarang berlangsung

Lain halnya dengan Subhi Mahmasani membagi sejarah pertumbuhan dan perkembangan hukum kedalam lima periode yaitu:

1) Periode perundang-undangan di zaman Nabi Muhammad saw

1 Pendapat para anggota kelompok4

2) Periode al-khulafa' al-Rasyidun (Empat khalifah besar)

3) Periode Abbasiyah

4) Periode taklid

5) Periode kebangkitan ${ }^{2}$

Secara umum, tahap-tahap perkembangan dan pertumbuhan hukum islam yang sebenarnya ialah:

1) Masa Nabi Muhammad (610 M-632 M)

2) Masa Khulafah Rasyidin (632-662)

3) Masa pembinaan, pengembangan dan pembukuan (abad VII-X M)

\footnotetext{
1 Agil Said Husin Al-Munawar, Hukum Islam Dan Pluralitas Sosial, Jakarta: Pt. Penamadani, 2004. hlm. 28

2 Ahmad Musyahid, Validasi Studi Orientalisme Terhadap Sejarah Sosial Hukum Islam, Makassar: Alauddin University Press, 2011.hlm.29-30
} 
4) Masa kelesuan pemikiran, pengembangan dan pembukuan (abad X M-XIX M)

5) Masa kebangkitan kembali (abad XIX M sampai sekarang) ${ }^{3}$

Setelah mengalami kelesuhan, kemunduran beberapa abad lamanya, pemikiran islam bangkit kembali. Ini terjadi pada abad ke-19. Kebangkitan kembali pemikiran islam timbul sebagai reaksi terhadap sikap taklid tersebut yang telah membawa kemunduran hukum islam. muncullah gerakan-gerakan baru diantara gerakan para ahli hukum yang menyarankan kembali kepada al-qur'an dan sunnah. Gerakan ini sering disebut gerakan modernis atau gerakan salaf (salafiyah) yang ingin kembali kepada kemurnian ajaran islam di zaman salaf (permulaan), generasi awal dahulu. ${ }^{4}$

Sikap keberagaman umat Islam di Dunia yang cenderung fatalistik, semaraknya gerakan modernisme di Timur Tengah dan interaksi dengan peradaban Barat yang dibawah penjajahan belanda akhirnya melahirkan gerakan pembaharuan islam di Indonesia.mereka tampil membawa pembaharuan-pembaharuan seperti pembukaan pintu ijtihad, pemanfaatan potensi akal secara maksimal, kebebasan berbuat dan pemurnian ajaran islam dari praktik-praktik taqlid, bid'ah, dan churafat (TBC). ${ }^{5}$

Gerakan modernis Islam dapat dipahami sebagai gerakan yang muncul pada periode sejarah Islam modern. Gerakan ini merupakan aliran dalam Islam yang pola pikir sesuai dengan perkembangan modern. Modernisme Islam adalah gerakan untuk mengadaptasi ajaran Islam kepada pemikiran dan kelembagaan modern. Modernis dalam bahasa Arab sering diasosiasikan dengan istilah tajdid, yang diartikan pembaharuan. Tokohnya disebut mujaddid, berarti pembaharu. ${ }^{6}$

\section{B. Modernisme menuju rasionalisasi ajaran Islam}

Kata "modern" berasal dari bahasa latin, modo, modernus, yang berarti "sekarang" atau "baru saja". Dalam Kamus Besar Bahasa Indonesia, modern berarti 1)terbaru, mutakhir; dan 2)sikap dan cara berpikir serta bertindak sesuai dengan tuntutan zaman. ${ }^{7}$ Dalam kamus oxford, kata modern diartikan sebagai "pandangan atau metode modern, khususnya kecenderungan untuk menyesuaikan tradisi, dalam masalah agama agar harmonis dengan pemikiran pemikiran modern". ${ }^{8}$

Menurut Muhammad Arkuon istilah modernisasi itu berasal dari kata modernus ( bahasa latin) yang pertama kali dipakai oleh kalangan Kristen sekitar tahun 490 M (filsafat Helenik dan Romawi) yang menunjukkan adanya perpindahan

\footnotetext{
${ }^{3}$ Mohammad Daud Ali, Pengantar Ilmu Hukum dan Tata Hukum islam di Indonesia, Jakarta: Raja Grafindo Persada, 2012.hlm.151

${ }^{4}$ Mohammad Daud Ali, Pengantar Ilmu Hukum dan Tata Hukum islam di Indonesia, Jakarta: Raja Grafindo Persada, 2012.hlm.197.

${ }^{5}$ Muhammad Iqbql, Hukum Islam Modern, Tangerang: Gaya Media Pratama, 2009.hlm.81.

${ }^{6}$ Azizy Qodri, Reformasi Bermzhab, Jakarta: Teraju, 2003. hlm. 82

${ }^{7}$ Tim Penyusun Kamus, Kamus Besar Bahas Indonesia. hlm.751.

${ }^{8}$ Kamus Oxford Dictionary, (Oxford University Press, 1987), h.240.
} 
dari masa Romawi lama ke periode Masehi.Sedangkan Modernization bermakna pembaharuan, selanjutnya kata modernism ( Modernism) is modern views or method especially tendency in matter or regious belief to subordinate tradition to harmony with modern thought. ${ }^{9}$

Menurut Fazlur Rahman (1919-1988), tokoh Neo-Modernisme Islam dari Pakistan, gerakan modernisme adalah gerakan yang berusaha merumuskan kembali nilai-nilai dan prinsip-prinsip Islam dalam batasan-batasan pemikiran modern dan mengintegrasikan pemikiran dan lembaga-lembaga modern dengan Islam. ${ }^{10}$

Sementara A. Mukti Ali mengartikan modernisme sebagai paham yang bertujuan untuk memurnikan Islam dengan cara mengajak umat Islam untuk kembali kepada Al-Quran dan Sunnah dan mendorong kebebasan berpikir sepanjang tidak bertentangan dengan teks Al-Quran dan Hadis yang shahih. ${ }^{11}$

Dari uraian tersebut, dapat dirumuskan bahwa pengertian reformisme, modernism atau pembaruan adalah paham yang berusaha melakukan aktualisasi kembali (reaktualisasi) sesuatu yang sebelumnya dianggap actual, namun perkembangan masa dan tempat, ia menjadi tidak actual lagi dan kehilangan relevansi. Bila dikaitkan dengan hukum Islam, modernisasi diartikan sebagai upaya yang sungguh-sungguh untuk melakukan interpretasi ulang terhadap pemikiran hukum Islam generasi mujtahid terdahulu, karena tidak sesuai lagi dengan perkembangan situasi masyarakat dan tuntutan zaman. Dalam hal in,i modernisasi atau pembaruan hukum Islam, melalui mekanisme ijtihad, berarti upaya melakukan pemahaman dan penafsiran terhadap Al-Quran dan Hadis Nabi SAW. secara kreatif, sehingga antisipatif terhadap perkembangan zaman. Karenanya, hasil ijtihad para ulama terdahulu yang tertuang dalam kitab-kitab fiqih mereka bukanlah sesuatu yang sacral. Namun ini tidak berarti bahwa pemikiran hukum Islam para mujtahid tersebut yang tertuang lewat karya-karya monumental mereka tidak kontekstual dan kaku. Karya mereka itu merupakan yang terbaik pada masanya. Yang kaku justru usaha-usaha umat Islam sepeninggal mereka yang ingin mengekalkan karya-karya tersebut dan menjadikannya sebagai landasan dalam menjawab permasalahan kekinian. ${ }^{12}$

Sebagaimana halnya gerakan tradisionalisme, gerakan pembaruan ini juga lahir dilatarbelakangi oleh situasi dan kondisi internal dan eksternal umat Islam. Uraian berikut akan memaparkan kondisi demikian. ${ }^{13}$

\footnotetext{
${ }^{9}$ Jurdi, Syarifuddin, Modernisasi pemikiran islam di Indonesia, Makassar: Alauddin University Press,

${ }^{10}$ Fazlur Rahman, Islam, (New York: Anchor Books, 1968), h.273.

11 A.Mukti Ali, Beberapa Persoalan Agama Dewasa Ini, (Jakarta: Rajawali Pers, 1988), h.54.

12 Azizy Qodri, Reformasi Bermzhab, Jakarta: Teraju, 2003. hlm.35

${ }^{13}$ Khallaf, Abdul Wahab, Politik Hukum Islam, Yogyakarta: Pt. Tiara Wacana, 1994. hlm. 62
} 2011.hlm.23 


\section{Faktor-faktor yang melatarbelakangi munculnya kelompok modernis \\ 1) Faktor Internal}

Pentingnya melakukan kajian ulang terhadap pemikiran masa lalu dilandasi oleh kenyataan bahwa sebagian umat islam generasi pasca imam-imam mujtahid menganggap karya-karya para mujtahid sebelum mereka bersifat universal dan lestari.

2) Faktor eksternal

Penjajahan barat terhadap hampir seluru dunia islam, termasuk indonesia yang dijajah belanda, membuat kondisi umat islam semakin memprihatinkan. ${ }^{14}$

Nilai-nilai pembaharuan (Modernisasi Islam) mempunyai pengaruh besar dalam kehidupan umat islam, sehingga akibat gerakan pembaharuan yang tersiar di kalangan negara-negara islam, maka tumbulah rasa kesadaran pada umat islam untuk mengikuti gerakan pembaharuan tersebut, sehingga menimbulkan suatu "kebangkitan dunia islam", baik dalambidang ilmu pengetahuan, pendidikan dan politik dan sekaligus tumbuh gerakan menentang penjajahan.

Kebangkitan dunia islam tersebut dilatarbelakangi oleh adanya negara islam, satu demi satu jatuh ketangan bangsa barat yang giat menyebarkan agama kristen di abad 18-19 M. Umat islam mulai sadar betapa berat penderitaan yang dialami dibawah penjajahan orang kristen. Maka mulailah mengintropeksi diri dalam segala aspek kehidupan, bidang agama, politik, sosial, budaya, ekonomi dan lain-lain. ${ }^{15}$

\section{Karakteristik kelompok modernis}

Pandangan kaum modernis yang mengutamakan pemanfaatan akal membawa mereka pada pendekatan yang rasional terhadap ajaran-ajaran Islam. Kalangan modernis berpandangan bahwa Islam adalah agama yang rasional, yang dapat menerima ide-ide baru yang progresif, sejauh tidak bertentangan dengan prinsipprinsip ajaran Islam itu sendiri. Tidak ada satu pun ajaran-ajaran Islam yang bertentangan dengan akal sehat. Ada dua metode yang dapat dikembangkan bila terdapat pertentangan antara wahyu dan akal. Pertama, wahyu harus diterima sebagai kebenaran yang absolute; dan kedua, mungkin akal manusia belum mampu menjangkau dan memahami maksud wahyu tersebut. Oleh karena itu, antara akal dan wahyu terdapat hubungan yang harmonis. ${ }^{16}$

Disamping itu, kelompok modernis, berdasarkan pandangannya yang rasional diatas, sangat percaya pada hukum kausalitas (hukum sebab akibat). Menurut Abduh, Islam didasarkan pada kepercayaan tentang hubungan sebab akibat. Kejadian di ala mini selalu didasarkan pada hubungan sebab akibat. Pada gilirannya, kaum modernis tidak percaya pada keajaiban. Semua kejadian di ala mini berjalan

${ }^{14}$ Muhammad Iqbal, Hukum Islam Modern, Tangerang: Gaya Media Pratama, 2009.hlm.78-80.

${ }^{15}$ Munir dan Sudarsono, Aliran Modern Dalam Islam, Jakarta: Rineka Cipta, 1996.hlm.147

${ }^{16}$ Mazheruddin Siddiqi, Modern Reformist Thought in the Muslim World, (New Delhi; Adam Publisher, 1993), h.1. 
dan terjadi hanya bedasarkan hukum sebab akibat. Kelompok modernis juga menolak praktik-praktik sufisme yamg melemahkan semangat manusia. Sufisme, menurut kelompok modernis, mengajarkan manusia pada sikap pasif dalam kehidupan. Namun harus dibedakan antara sufisme sebagai pemikiran teologi dan sikap hidup. Sufisme dalam bentuk pemikiran teologis pada gilirannya mengajarkan konsep wahdah al-wujud yang menafikan keberadaan dan usaha manusia. Inilah yang melahirkan sikap jabariyah (fatalistis) dan pasif dalam kehidupan manusia serta ditolak oleh kelompok muslim modernis. Sedangkan sufisme dalam bentuk sikap hidup tidak ditolak oleh kelompok modernis. Mereka bersiakap apresitif terhadap ajaran-ajaran moral sufistik seperti qana'ah, 'isyq, ikhlas dan lain-lain. Ajaran-ajaran tersebut dinilai positif dalam kehidupan beragama umat Islam. ${ }^{17}$

Saat ini CIA melakukan sebuah penemuan yang penemuannya itu mirip temuan dari Rusia; bahwa tahun 2020 akan hadir sebuah peradaban baru, yang terbentang dari sebelah timur Cina sampai sebelah barat Samudera Atlantik. Peradaban baru itu bernama Khilafah Islamiyah". ${ }^{18}$

Di Indonesia sendiri terdapat gerakan pembaharu yang bertujuan untuk membersihkan islam dari berbagai khurafat dan bidah, maka program-program yang di garap untuk mencapai tujuan itu, meliputi beberapa aspek, seperti:

1) Mensucikan islam dari pengaruh bidah

2) Pendidikan yang lebih tinggi dari kaum muslimin

3) Pembaharuan rumusan ajaran Islam menurut alam pikiran modern

4) Pembelaan islam terhadap pengaruh barat (sekuler) dan ajaran kristen. ${ }^{19}$

Kajian terhadap sejarah sosial hukum islam selanjutnya mengalami perkembangan pesat hingga menjadi suatu ilmu setelah munculnya berbagai hasil penelitian ilmiah yang dilakukan para sarjana dibarat. Mereka meneliti dinamika sejarah perkembangan hukum islam sejak zama klasik hingga zaman modern. ${ }^{20}$

Periode ushul fiqih secara politik ditandai mulai melemahnya dinasti Abbasiyah akibat kekacauan politik dan diintegrasi wilayah-wilayah kekuasaannya. Tetapi dibalik degras kekuasaan politik Abbasiyyah itu justru sebaliknya secara diamentral semakin pesatnyakegiatan ilmiah dan perkembangan ilmu yang jauh lebih maju dibanding era sebelumnya. ${ }^{21}$

Disaat al-mutawakkil menjadi penguasa dalam daulah Abbasiyah dan untuk memperkuat kedudukannya, ia mencari dukungan dari mayoritas masyarakat awwam yang merupakan penganut sifatiya yang menentang ajaran Mu'tazilah. Mereka mengeluarkan minoritas rasionalis dari kekuasaan Negara, melarang

\footnotetext{
${ }^{17}$ Muhammad Iqbal, Hukum Islam Indonesia Modern, h. 82.

${ }^{18}$ Munir dan Sudarsono, Aliran Modern Dalam Islam, Jakarta: Rineka Cipta, 1996.hlm.147

${ }^{19}$ Munir dan Sudarsono, Aliran Modern Dalam Islam, Jakarta: Rineka Cipta,1994. hlm.156.

${ }^{20}$ Ahmad Musyahid, Validasi Studi Orientalisme Tehadap Sejarah Sosial Hukum Islam, Makassar: Alauddin Universiry Press, 2011.hlm.31.

${ }^{21}$ Abdul Mughits, Kritik nalar fiqih Pesantren, Jakarta: Kencana Prenada Media Group.2008.hm.61.
} 
pengajaran filsafat dan ilmu pengetahuan dan bahkan kaum rasioanalis sendiri diusir dari Bagdad. Maka rasionalisme Mu'tazilah dan pada akhirnya teologi yang baru inilah yang menguasai dunia islam dan filsafat secara rasionalisme mengalami kekalahan. ${ }^{22}$

\section{E. Kondisi Hukum Islam Masa Kini}

Sebagaimana telah anda ketahui pembicaraan hukum pada periode-peride sebelumnya bahwa ijtihad bergerak pada langkah pertumbuhan hingga mencapai puncak ketinggiannya; pada periode kedua dan ketiga para sahabat dan tabi'in sibuk mencurahkan kemampuannya dalam menjelaskan cara-cara istinbat dari Kitab Allah dan Sunnah Rasul-Nya dan melukiskan langkah kerja yang akan diikuti oleh para ahli fikih sesudah mereka. Kemudian datang periode keempat, pertumbuhan ilmiah sangat maju, banyak bermunculan para mujtahid, banyak bermunculan hukumhukum dan penyusunan ushul dan kaidah-kaidah. Disamping itu, ada juga para ulama dan fuqaha pada masa-masa ini banyak mengikuti (muqallid) terhadap orangorang yang mampu berijtihad dalam mengeluarkan hukum-hukum, karena ijtihad itu keras yang tidak bias dilakukan kecuali bagi ulama khusus yang banyak memiliki sebab-sebabnya dan sempurna perangkatnya. Pada periode kelima, meskipun kelesuan merasuki jiwa para ulama dan menyebarnya taklid hingga mengungkung orang umum dan khusus namun diantara mereka ada yang memilki kemampuan yang tinggi dalam mentakhrij, mentarjih dan ijtihad dalam madzhab atas berbagai masalah. ${ }^{23}$ Adapun periode keenam terbagi kepada dua bagian yaitu:

Pertama, sampai awal-awal abad kesepuluh. Pada masa ini muncul ulama pandai seperti syekh kholil Al-Maliki, As-Subki, Ar-Ramli, ibnu Ar-Rif'ah, Al-Kamal Ibnu Al-Hammam As-Suyuti dan yang lain sebagainya yang memiliki kekuatan fiqih (pemahaman) dan memiliki kemampuan melakukan istimbat, hanya saja mereka tidak memanfaatkan kemampuan ini sebagaimana yang dilakuakan para ulama sebelumnya dalam berijtihad dan mentakhrij tetapi mereka arahkan pada penyusunan, perubahan, dan mengarah kepada peringkasan serta pengumpulan berbagai masalah cabang dalam ungkapan-ungkapan yang sempit menyerupai tekateki, dan memerlukan waktu yang lama untuk memahaminya dan untuk mengetahui maksudnya sehinnga memerlukan penyusuna kitab-kitab lain yang menjelaskan (mensyarah) kesamarannya, membuka ikatannya dan mengungkap tujuan sipengarang penyusunnya. ${ }^{24}$

Kedua, sejak abad kesepuluh sampai sekarang. Pada masa ini kondisi fiqih banyak memburuk, hal ini terjadi karena:

\footnotetext{
${ }^{22}$ Soraya Rasyid, Sejarah Islam Abad Modern, Makassar: Alauddin University Press.2012.hlm.127

${ }^{23}$ Abdul Mughits, Kritik nalar fiqih Pesantren, Jakarta: Kencana Prenada Media Group.2008.hm.32

${ }^{24}$ Muhammad Ali As-Sayis, Sejarah Fiqih Islam, h. 174.
} 
1. Para ulama telah memalingkan kemampuannya untuk mempelajari kitab-kitab yang sukar ini dan memutuskan hubungannya dengan kitab-kitab yang berharga tinggi tersebut yang ditinggalkan para ulama terdahulu (sebelumnya).

2. Terputusnya hubungan antara ulama kota-kota Islam, padahal sebaik-baiknya washilah untuk mengambil ilmu dan meluruskan jalan yang menjurus ke hal itu adalah bertemu langsung kepada orang pandai secara lisan dan hal itu tidak akan tercapai kecuali dengan memperbanyak perjalanan ilmiah.

3. Karena telah banyak karangan dan penyusunan ilmu-ilmu dan perangkatnya, ternyata hal ini menjadi sebab kemiripan, pencampuran dan seidenya peneliti fiqih tentang ijtihad dan istimbat. ${ }^{25}$

\section{F. Sistem Mempelajari Fiqih di Masa Modern}

Kenyataan yang sangat nampak dari kebangunan fiqih islam di masa ini, ialah mempelajari secara ilmiyah dan akademis. Inilah yang telah menghasilkan faedah yang sangat besar. Didalam universitas bertemulah para sarjana hukum umum dan para sarjana fiqih islam. Dengan demikian hasillah suatu perbandingan hukum. Adanya studi-studi tinggi dalam bidang syariah mempunyai nilai tinggi yang telah diberikan untuk perkembangan fiqih islam. Karena itu sistem yang dipakai dalam mempelajari fiqih, ialah secara perbandingan (Fiqih Munakahat). ${ }^{26}$

\section{G. Tokoh-Tokoh Tajdjid (Pembaru) Islam Masa}

1) Gerakan yang timbul di Arabia, yang dipelopori oleh Muhammad Ibn Abd. Wahab (1703-1787) yang akhirnya dikenal dengan gerakan wahabiah. Gerakan ini lahir bukan karena pengaruh kemajuan barat, tetapi sebagai reaksi terhadap paham tauhid yang di anut oleh kaum awam di waktu itu. Kemurnian paham tauhid mereka telah dirusak oleh kebiasaan-kebiasaan yang timbul dibawah pengaruh tarekat-tarekat seperti pujaan dan kepatuhan yang berlebihan pada syegh-syegh tarekat, ziarah kekuburan-kuburan wali dengan maksud meminta syafaat atau pertolongan dari mereka atau sebagainya. Menurut beliau kebiasaan-kebiasaan itu mengandung syirik atau politeisme dan harus diberantas. Semuah itu adalah bidah (sesuatu yang asing) yang di bawah orang luar masuk ke dalam islam. Bidah itu mesti dibuang dan orang harus kembali kepada tauhid dan islam yang sebenarnya. Tauhid dan islam yang murni, terdapat pertama-tama pada wali muhammad yang kemudian pada sahabat. Imam-imam dan ulama-ulamabesar mereka ini di sebutsalaf islam sesudah zaman salaf banyak dimasuki bidah. Untuk memurnikan islam semua bidah itu mesti dibuang. ${ }^{27}$

${ }^{25}$ Muhammad Ali As-Sayis, Sejarah Fiqih Islam, h. 176.

${ }^{26}$ Teungku Muhammad Hasbi Ash Shiddieqy, Penganta Ilm Fiqih, Semarang: Pustaka Rizki Putra. 1999.hlm.88

${ }^{27}$ Harun Nasution, Islam ditinjau Dari Berbagai Aspeknya, Jilid II, Jakarta: UI Press, 1984-1985.hlm.95. 
2) Tokoh pembaruan di Turki bernama Sultan Abdul Hamid (1725-1789), mempelopori garakan khilafat yang bertujuan membina persatuan seluruh dunia Islam, berada dalam satu khilafat dalam menghadapi perkembangan bangsa Barat.

3) Tokoh pembaharuan di Aljazirah bernama Muhammad bin Sanusi (1791-1859). Ia memimpin gerakan solidaritas yang di sebut gerakan Tharoqat Sanusiyah.

4) Tokoh pembaharuan islam lainnya adalah Syegh Waliyatullah (1703-1762). Mula-mula ia seorang pendidik dan pengarang. Ia melihat kelemahan umat islam yang di karenakan:

a. Perubahan sistem pemerintahan Islam dari kekhalifahan ke sistem kerajaan,

b. Perubahan dari sistem demokrasi ke otokraksi/absolut.

c. Perpecahan di kalangan umat islam yang disebabkan timbulanya aliranaliran.

d. Masuknya adat-istiadat dan ajaran bukan Islam kedalam keyakinan umat Islam.

Terdorong dari beberapa sebab tersebut, syeagh Waliyatullah menyerukan kembali ke sistem pemerintahan seperti yang dilakukan oleh khulafaurrasyidin dengan mengutamakan demokrasi dan kepentingan rakyat dalam pemerintahan. ${ }^{28}$ Hingga pada masa kini dampak dari pergerakan mereka masih tercermin dalam organisasi-organisasi islam yang bergerak untuk membela islam dan membangun generasi islam. lebih pada ide-ide dan pembaharuan yang dilakukan pada pembaharu tersebut, juga apa sumbangan nyata yang mereka berikan dan dapat kami manfaatkan hingga sekarang. ${ }^{29}$

Pada abad ke-19, semakin bertambah jelas kebangkitan umat islam di seluruh pelosok dunia Islam. Gerakan-gerakan pembaru Islam pada abad ke-19 ini, adalah sebagai penerus atau kelanjutan dari abad sebelumnya. Diantara pembaru atau mujaddid di abad ke -19 M adalah:

1) Al-Tahtawi (1801-1873)

Nama lengkapnya adalah rifaah Badawi Rufi Al-Tahtawi, seorang pemikir pembaruan dunia Islam. Ia mendalami ilmu-ilmu Barat dari Sarja Prancis dan dari pergaulannya dengan ulama Al-Azhar.

2) Muhammad Abduh (1849-1905)

Ia putra Mesir darikeluarga petani miskin. Ketika masih menyelesaikan belajarnya di Universitas al-Azhar Mesir, ia bertemu dengan tokoh dan penggerak Pan Islamisme Jamaluddin Al-Afgani yang kebetulan menetap di Mesir selama 8 Tahun. Sebagai tokoh gerakan Pan islamisme dan murid Jamaluddin, ia telah13banyak menduduki jabatan-jabatan penting. Ia diusir dari Mesirbersama

\footnotetext{
${ }^{28}$ Munir dan Sudarsono, Aliran Modern Dalam Islam, Jakarta: Rineka Cipta.1984.hlm.158.

29 Teungku Muhammad Hasbi Ash Shiddieqy, Penganta Ilm Fiqih, Semarang: Pustaka Rizki Putra. 1999.hlm.88
} 
Jamaluddin karena terlihat dalam resolusi Urabi Pasya.dari Mesir, ia berdua menuju ke Paris. Disana mereka mendirikan organisasi dan menerbitkan majalahAl-Urwatul Wusqa.

3) Jamaluddin Al-Afghanistan (1839-1897)

Ia seorang tokoh kebangsaan Afganistan, lahir di Assabadad Persi dan wafat di Istanbul. Ia memiliki kecerdasan otak yang luar biasa, pribadinya sangat menarik dan penuh semangat. Ia banyak memperoleh pengalaman dalam pengembaraannya ke berbagai negara. Mula-mula ke India, kemudian ke Mesirmemberi kuliah, ceramah dan diskusi kepada kaum intelektual di Al-Azhar.

4) Muhammad Rayid Ridha (1865-1935)

Tokoh inikelahiran Al-Qalamun Libanon, ia belajar kepada seorang guru Syegh Husein Al-Jasr, Mufti Besar Tripoli, kemudian tahun 1898 pindah ke Mesir, berguru kepada Muhammad Abduh. Di Mesir bersama-sama Muhammad Abduh (gurunya)menerbitkan majalah Al-Manaryang bertujuan sama dengan Al-Urwatul Wusqa di Paris

5) Sultan Mahmud dari Turki (1785-1839)

Ia lebih menitipberatkan pada pembinaan di bidang militer. Melihat kerajaan dalam kelemahan, maka perlu membentuk korps baru yang dilatih oleh pelatih dari Eropa. Ia lebih bersikap demokratis dan menghapus adat-istiadat yang mengganggu serta mengurangi hak-hak kaum bangsawan.

6) Sayyid Alkman Khan (1817-1898)

Ia lahir di Delhi tahun 1817 sebagai putrab seorang bangsawan tnggi. Sayyid Akhman Khan sebagai pelopor gerakan modernisme dalam Islam, yaitu sebagai kelanjutan gerakan mujahidin yang didirikan oleh Syegh Walliyatullah as Dahlawi Bangsa Inggris memberi gelar "sir" karena jasanya menyelamatkan orang-orang inggris ketika terjadi pemberontakan pada tahun 1857.

7) Muhammad Iqbal (1896-1939)

Seorang tokoh kelahiran Punjab memperoleh gelar MA di lahore. Ia melanjutkan studunya ke Universitas Munich Inggris tahun 1905 memperdalami filsafat. ${ }^{30}$

Kondisi Umat Islam Di Negara-Negara Minoritas Muslim Pada Periode Modern

1) Umat Islam di Eropa

Islam telah mengalami kemajuan berabat-abad lamanya. Seandainya Bangladesh tidak jatuh di tangan pasukan tartar (mongol) pada tahun $1258 \mathrm{M}$, yang disusul dengan penghancuran pusat-pusat keilmuan di kota ini, dan seandainya bangsa barat tidak menemukan jalur perdagangan laut pada abad ke-15, entah seperti apa hebatnya dunian Islam sekarang. Sayangnya, sejarah tidak bisa di ajak

${ }^{30}$ Harun Nasution, Islam ditinjau dari Berbagai Aspeknya, Jilid II, Jakarta: UI Press, 1984-1985.hlm.159- 
berandai-andai. Sejarah adalah sebuah fakta dan realitas yang terjadi, karena itulah ia disebut sejarah karena jarum jam perjalanan sejarah tidak bisa diputar mundur kembali.

2) Umat islam di Amerika

Amerika adalah sebuah benua dan Negara yang menjadi tumpuan perhatian bagi bannyak Negara di Dunia, baik dari segi politik, ekonomi maupun agama. Masuknya Islam di Amerika bersifat spekulatif karena tidak adanya data yang secara tegas menginformasikan tentang masuknya Islam di Amerika. Sebagian ahli sejarah berpendapat bahwa para pelaut muslim adalah orang-orang pertama yang menyebrangi Samudera Atlantik dan tiba di pantai-pantai Amerika. Sebagian yang lain mengatakan bahwa, Cristopur Columbus telah dibimbing untuk mendarat di Benua itu oleh navigator-navigator dan pembantu-pembantu muslim di Andalusia atau Maroko yang jasa-jasanya telah di bayar oleh Columbus. $^{31}$

Dari masa kemasa kehidupan masyarakat pasti akan mengalami perubahan baik itu proses perubahannya secara cepat ataupun secara lambat, direncanakan atau tidak. Perubahan sosial pada intinya adalah faktor dinamika manusianya yang kreatif yang anggota masyarakatnya bersikap terbuka, secara kreatif menciptakan kondisi perubahan terutama dalam bidang ekonomi dan pol hidup sehari-hari didalam proses perubahan terkadang diselingi konflik, konflik yang terjadi di kehidupan masyarakat. Kemudian didalam era modern, syarat umum modernisasi dalam kehidupan masyarakat. ${ }^{32}$

\section{H. Kondisi Umat Islam Di Negara-Negara Mayoritas Muslim Pada Periode Modern \\ 1) Islam di Asia Barat}

Hampir semua Negara di Asia Barat (kecuali Israil, Libanon, Cyprus) penduduknya mayoritass beragama Islam. Di wilayah ini, islam lahir pada abad ke-7 M. Dan disini pula dakwah Islam menyebar luas. Kawasan yang mayoritas yang terdiri atas bangsa Arab, memainkan peranan penting dari segala peristiwa yang berkaitan dengan sejarah Islam. Karena itu, wilayah ini di sebut juga sebagai “Jantung dunia Islam".

2) Islam di Iran

Iran adalah Negara Timur tengah yang terletak di Asia barat Daya. Nama Iran berasal dari kata "Aryan" yang berarti tanah bangsa Arya. Revolusi Islam Iran sangat berpengaruh terhadap perkembangan masyarakat Iran dan kebangkitan ilmu

\footnotetext{
${ }^{31}$ Soraya Rasyid, Sejarah Islam Abad Modern, Makassar: Alauddin University Press. 2012.hlm.151-153.

${ }^{32}$ Munir dan Sudarsono, Aliran Modern Dalam Islam, Jakarta: Rineka Cipta.1984.hlm.158.
} 
pengetahuan dan tekhnologi Pasca revolusi Islam Iran mebuat Iran semakin berkembang darn menjadi negara yang maju dan berpendapatan tinggi. ${ }^{33}$

Di dunia ini, sekurang-kurangnya ada lima sistem hukum besar yang hidup dan berkembang. Sistem-sistem hukum tersebut adalah:

a. Sistem Hukum Adat yang pada umumnya berlaku di Asia dan Afrika

b. Sistem Hukum Islam yang di anut oleh orang-orang islam dimanapun mereka berada, baik di negara islam maupun di negara-negara lain yang penduduknya beragama islam seperti di Afrika Utara dan Timur, Timur tengah, Asia, di beberapa negara Eropa, dan juga di beberapa negara Amerika.

c. Sistem Hukum Eropa Kontinental yang berasal dari hukum romawi, terutama setelah melalui proses resepsi, menjadi hukum yang berlaku di Eropa Barat.

\section{Aplikasi Metodologi Fikih Realitas dalam Kasus Fikih Kontemporer}

1. Kasus Multi Level Marketing (Fikih Ekonomi)

Multi Level Marketing (MLM) merupakan salah satu model bisnis yang marak diganrungi oleh pelaku bisnis dalam satu dekade ini. Dalam literatur Islam semua bisnis yang termasuk kategori muamalah yang dibahas dalam bab al-buyu' Hukum asal setiap bisnis secara prinsip adalah boleh berdasrkan kaedah "al-Ash fi al-Asya' al-Ibadah" / Hukum asal sesuatu termasuk muamalah adalah boleh "selama bisnis tersebut bebas dari unsur-unsur haram seperti riba (Sistem bunga), garar (tipuan), jahalah (Ketidak jelasan), dzulm (merugikan hak orang lain) disamping barang atau jasa yang dibisniskan adalah halal.

Melihat praktik bisnis yang di tampilkan oleh Multi Level Marketing (MLM) ini, bias di analisis melalui pintu jualalah yaitu sayembara untuk mendapatkan seseuatu dengan bonus tertentu. Akad ju'alah ini tercermin dalam QS. Yusuf (12):72:

Terjemahannya;

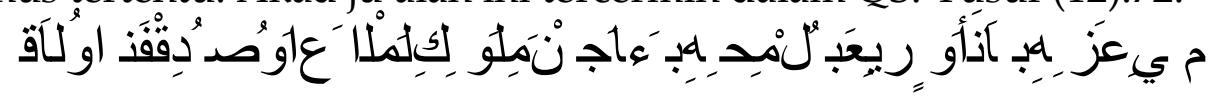

"penyeru-penyeru itu berkata: "kami kehilangan piala raja, dan siapa yang dapat mengembalikannya akan memperoleh bahan makanan (seberat) beban unta, dan aku menjamin terhadapnya". ${ }^{34}$

2. Kasus Poligami ( Fiqih Perempuan )

Pembahasan mengenai poligami cukup alot diperbincangkan oleh berbagai kalangan baik dari kalangan ulama maupun dari kalangan penggiat gerakan fesimis. Dengan merujuk kepada al-qu'an mengenai ppoligami, hendaknya pandangan alqur'an tidak di pandang dari segi ideal atau baik dan buruknya, tetapi harus dilihat

\footnotetext{
${ }^{33}$ Soraya Rasyid, Sejarah Islam Abad Modern, Makassar: Alauddin University Press. 2012.hlm.177-185.

34 Wahid Haddede, Menggagas Metodologi fiqih Realitas, Makassar: Alauddin University Press.2011.hlm 120-121

35 Ali, Mohammad Daud Haji, Lembaga-Lembaga Islam di Indonesia, Jakarta Utara: Raja Grafindo Persada.1995.hlm.123.
} 
dari sudut pandang penetapan hukum dari aneka kondisi yang mungkin terjadi, serta melihat pula sisi aneka alternatif yang menjadi tawarannya. ${ }^{36}$

3. Kemana UIN Mengembangkan program pendidikannya ? (Fiqih pendidikan)

Setelah melakukan redifisi terhadap jargon "Islamisasi pengetahuan", agaknya Civitas Akademika UIN perlu menghargai dan menanggapi secara positif terhadap upaya kebangkitan pemikiran islam yang berkembang hingga saat ini yang dilontarkan oleh para cendikiawan Muslim. Sessungguhnya mereka memiliki perspektif yang berbeda-beda, namun pemikiran-pemikiran mereka agaknya masih berada dalam koridor islami. ${ }^{37}$

\section{J. Biaya hidup dalam keluarga Modern}

Ulama Hanafi dan Malik menyatakan bahwa penjual memiliki tanggung jawab untuk biaya hidup dan dan hak untuk meningkatkan. Seperti yang kita ketahui, bahwa suamilah yang harusnya mencukupi kebutuhan keluarga. Jika hal itu tidak cukup untuk menunjang kehidupan keluarga, atau penghasilannya tidak memenuhi untuk menyediakan kehidupan yang semestinya, dan jika istri bersedia, keduanya dapat bekerja untuk mendapatkan penghasilan. Tetapi:

a. Suami berhak untuk mengakhiri pekerjaan yang dilakukan oleh istri apabila istrinya tidak sanggup lagi.

b. Dia berhak untuk menolak pekerjaan apapun jika ia merasa bahwa itu akan membahayakan istrinya sendiri, seperti rayuan atau penghianatan.

c. Istri berhak untuk menghentikan pekerjaannya kapanpun dia mau.

d. Keuntungan dari istri dmiliki bersama dan tidak dianggap sebagai milik pribadi. ${ }^{38}$

\section{KESIMPULAN}

Para penulis sejarah hukum islam telah mengadakan pembagian tahap-tahap pertumbuhan dan perkembangan hukum islam. Pembagian kedalam beberapa tahap itu tergantung pada tujuan dan ukuran yang mereka pergunakan dalam mengadakan pertahapan itu. Gerakan modernis Islam dapat dipahami sebagai gerakan yang muncul pada periode sejarah Islam modern. Gerakan ini merupakan aliran dalam Islam yang pola pikir sesuai dengan perkembangan modern. Modernisme Islam adalah gerakan untuk mengadaptasi ajaran Islam kepada pemikiran dan kelembagaan modern. Modernis dalam bahasa Arab sering diasosiasikan dengan istilah tajdid, yang diartikan pembaharuan. Tokohnya disebut mujaddid, berarti pembaharu.

Saat ini CIA melakukan sebuah penemuan yang penemuannya itu mirip temuan dari Rusia; bahwa tahun 2020 akan hadir sebuah peradaban baru, yang

\footnotetext{
${ }^{36}$ Wahid Haddede, Menggagas Metodologi fiqih Realitas, Makassar: Alauddin University Press.2011.hlm 124-125.

${ }^{37}$ Muhaimin, Nuansa baru pendidikan islam, Jakarta: RajaGrafindo.2006.hlm.65

${ }^{38}$ Rahman, Syari'ah The Islamic Law, Malaysia: Percetakan Zafar Sdn. Bhd. 1984/1404H.hlm.205
} 
terbentang dari sebelah timur Cina sampai sebelah barat Samudera Atlantik. Peradaban baru itu bernama Khilafah Islamiyah. Hingga pada masa kini dampak dari pergerakan mereka masih tercermin dalam organisasi-organisasi islam yang bergerak untuk membela islam dan membangun generasi islam. lebih pada ide-ide dan pembaharuan yang dilakukan pada pembaharu tersebut, juga apa sumbangan nyata yang mereka berikan dan dapat kami manfaatkan hingga sekarang.

Sebagai akhir kata dalam tulisan ini, kami mengucapkan puji syukur Alhamdulillah kehadirat Allah SWT yang telah melimpahkan rahmat dan petunjukNya sehingga kami dapat menyelesaikan tulisan ini. Saya sangat menyadari bahwa didalam penyusunan tulisan ini masih banyak kekurangan dan juga kesalahan yang butuh pembenahan, yang mungkin disebabkan oleh terbatasnya tenaga, waktu, biaya dan keterbatasan data dan pengetahuan yang saya miliki.

Oleh karena itu saya mengharapkan adanya kritik atau saran yang bersifat membangun demi perbaikan tulisan ini. Akhirnya saya berharap tulisan ini dapat bermanfat bagi pembaca. Dan segala puji bagi Allah SWT dan sholawat serta salam atas Rosul-Nya, semoga saya selalu dalam bimbingan, lindungan dan ridho-Nya. Aminnnn

\section{Daftar Pustaka}

Abidin, Zainal. Ijtihad Kontemporer dan Reformasi Hukum Islam. Aceh: Yayasan Haji Abdullah Amin.2003

Ali, As-sayir, Muhammad. Sejarah Fiqih Islam. Jakarta Timur: Pustaka Al-Kautsar. 2003

Ali, Daud, Muhammad. Pengantar Ilmu Hukum dan Tata Hukum Islam di Indonesia. Kota Depok: Raja Grafindo Persada. 2012

Ali, Daud, Mohammad dan Ali, Daud, Habibah. Lembaga-Lembaga Islam di Indonesia. Jakarta Utara: Raja Grafindo Persada. 1995

Ash Shiddieqy, Hasbi, Reungku Muhammad. Pengantar Ilmu Fiqih. Semarang: Pustaka Rizki Putra.1999

Haddade, Wahid. Menggagas Metodelogi Fiqih Realitas. Makassar: Alauddin University Press. 2011

Iqbal, Muhammad. Hukum Islam Modern. Tangerang: Gaya Media Pratama. 2009

Kharofa, Ala' Eddin.Transactions in Islmaic Law. Malaysia: Pustaka hayathi. 1997

Mughits, Abdul. Kritik Nalar Fiqih Pesantren, Jakarta: Kencana Prenada Media Grup. 2008

Muhaimin, Nuansa baru pendidikan islam. Jakarta: RajaGrafindo Persada. 2006

Munir. Aliran Modern Dalam Islam. Jakarta: Rineka Cipta. 1994 
Rahman. Syari'ah The Islamic law. Malaysia: A.S. Noordeen. 1984

Musyahid, Ahmad. Falidasi Studi Orientalisme Terhadap Sejarah Sosial

Hukum Islam. Makassar: Alauddin University Press. 2011

Rasyid, Soraya. Sejarah Islam Abad Modern. Makassar: Alauddin University Press.2012

Talib, Abdulla. Modernitasi pemikiran islam di Indonesia. Makassar: Alauddin Press. 2011

Wahid, Hadede, Abdul. Fiqih Realitas. Makassar: Alauddin University Press. 2011 